\title{
Service Management as a Subdiscipline of Management Science
}

\author{
Arkadiusz Rokicki ${ }^{1}$, Bogdan Nogalski²
}

Submitted: 16.01.2021. Accepted: 16.01.2021

\section{Abstract}

Purpose: To draw research attention to service management (SM) as a subdiscipline of management science. Service management offers a different, more customer-value-centric perspective that is scarcely present in management science studies, rooted in manufacturing and production management. The purpose is also to define the scope of SM as an area of research in management science.

Approach: This is a conceptual article that foregrounds ideas and arguments found in the subject literature. The article analyzes the ideas to build a coherent structure and context for future empirical research.

Findings: Service management as a research area evolved from being a subset of monitoring/production management to the forefront of management science thought. Service management provides management science with the capability for staying relevant in the practicing management community. Service management's importance in management science will continue to grow as there is an increasing number of companies with customer offers called "aaS" (as a Service). Service management presents a clear scope that provides another management science research area and enables it to evolve further.

Value: This article is not the first one to touch on the topic and evolution of SM. However, it is the first one to present SM as part of management science's evolution as an academic discipline and to highlight the dependencies and connections between the two. The article defines what SM is, why it matters for management theorists and practitioners, and how it will enable management science to grow further.

Keywords: service management, value creation, production management, management disciplines.

JEL: 1.8

\footnotetext{
Corresponding author, Kozminski University, 59 Jagiellonska St., 03-301 Warsaw, e-mail: arkadiusz.rokicki@yahoo.co.uk; https://orcid. org/0000-0002-5621-2040.

2 WSB University in Gdańsk, Institute of Management and Finance; Aleja Grunwaldzka 238A, 80-266 Gdańsk, Poland, e-mail: bogdannogalski. bn@gmail.com, https:// orcid.org/0000-0003-0262-8355.
} 


\section{Introduction: Services and Service Management}

The subject of this analysis is service management (SM), its scope, genesis, and above all, its place in management science. In 2014, SM was included in the subdisciplines of management by the Group for the Definition of Subdisciplines in Management Science, appointed on the initiative of Bogdan Nogalski (Cyfert et al., 2014, p. 42). According to this classification, service management is one of the seven subdisciplines of the functional level of management; along with logistics management, human resource management, marketing management, production and technology management, corporate financial management, and management of intangible assets. Due to changes in scientific fields and disciplines in Poland, the current name of the discipline, i.e. management science, was changed to management and quality sciences on April 9, 2019. This change made it necessary to review the existing subdisciplines. The new classification was prepared by an expanded team under the supervision of Szymon Cyfert, and composed of Grzegorz Bełz, Szymon Cyfert, Wojciech Czakon, Wojciech Dyduch, Dominika Latusek-Jurczak, Jerzy Niemczyk, Agnieszka Sopińska, Agnieszka Szpitter, Maciej Urbaniak, and Jan Wiktor. Service management was included in one of the subdisciplines - together with production and technology management - while maintaining its separate character (Bełz et al., 2019).

Adam Smith was one of the first to mention services alongside goods as part of economic thought (Sewall, 1901, p. 31). In the context of management, Oliver Sheldon published in 1921 a book called The Philosophy of Management, in which he explains that "Industry exists to provide the commodities and services which are necessary for the good life of the community" (qtd. after George, 1968, p. 125), which made Sheldon become one of the first management thinkers to recognize services.

There are many definitions of services, and they have changed over time. The often-cited definition by Hill from 1977 reads: "a change in the condition of a person, or a good belonging to some economic unit, which is brought about as a result of the activities of some other economic unit, with the prior agreement of the former person or economic unit" (Hill, 1977, p. 318). In his lecture at the 25th European Conference on Information Systems (ECIS) in Guimarães, Portugal, in June 2017, Prof. Steven Alter presented the following views on what services are (Alter, 2017, p. 1825-1826):

1. Service as acts for the benefit of others: this viewpoint situates the closest to the above definition and constitutes a starting point for other perspectives. It is akin to the views of leading management and service management theorists such as Kotler, Vargo, Lusch, and Grönroos. 
2. Service as a sector of the economy: services account for a significant share of GDP in most countries, and in countries considered developed this dominance is even more pronounced. According to data from 2015, employment in the world's largest countries in terms of the number of employees was as follows:

Table 1. Sector employment in top 10 nations by labor force size

\begin{tabular}{|l|c|c|c|c|}
\hline Country/Region & $\begin{array}{c}\text { \% of the world's } \\
\text { workforce }\end{array}$ & Agriculture \% & Industry \% & Services \% \\
\hline China & 21.2 & 33.6 & 30.3 & 36.1 \\
\hline India & 13.9 & 49 & 20 & 31 \\
\hline European Union & 6.4 & 5 & 21.9 & 73.1 \\
\hline United States & 4.3 & 0.7 & 20.3 & 79 \\
\hline of America & 3.4 & 38.9 & 13.2 & 47.9 \\
\hline Indonesia & 3 & 15.7 & 13.3 & 71 \\
\hline Brazil & 2.3 & 47 & 13 & 40 \\
\hline Bangladesh & 2.1 & 9.4 & 27.6 & 63 \\
\hline Russia & 1.8 & 2.9 & 26.2 & 70.9 \\
\hline Japan & 1.7 & 43.7 & 22.4 & 33.9 \\
\hline Pakistan & & & & \\
\hline
\end{tabular}

Source: Bordoloi et al. (2018, p. 3).

According to some authors (Inman, 1988; Walker, 2004; Buera and Kaboski, 2012), we currently live in times of service economy, namely an economy based on the provision of services. Alter emphasizes that the enormous share of the service sector in the economy does not translate into an understanding of individual services or an organization's service management systems. According to him, companies in the agricultural or manufacturing sectors also possess service management systems. When employing this viewpoint, we should note that the service-oriented approach is different from production management. We will elaborate on this matter in the second section.

3. Services as outcomes: a view popular in IT milieux, in which a service offered can be defined from the customer's perspective. The client is less interested in what activities are to be performed to deliver the service and more in the benefits that it may bring. Such a perspective is noticeable both in the work by Hill (Hill, 1977) and in the Information Technology Infrastructure Library 
(ITIL), a set of best practices in the field of IT service management (ITIL Service Strategy, 2011, p. 13).

4. Service as a response to a request: this view assumes that services consist of a customer's request and a service provider's response, which results in the focus on the format and content of requests, along with responses to them. However, this context may underestimate the service delivery system and operational activity themselves.

5. Services as co-production: this approach emphasizes the cooperation between service providers and recipients. It accentuates the fact that both parties are participants in the process. This cooperation may be limited to issuing an order for a service (as is often the case with IT services), but it may also be a long-term process, as it happens in educational services, physiotherapy, or software development and testing, in which the participation of clients in the process may be significant.

6. Services as value co-creation: in this view, services are part of the customer's process of obtaining value; the customer obtains some value from the service delivered by another entity. Alter indicates that there is an ongoing debate as to whether the creation of value is the result of a service being performed. It is also possible that customers create value themselves, whereas the supplier is only using the opportunity to support this process.

7. Services as economic exchange: in this sense, the service is an artifact transferred to the provider for remuneration, and this exchange constitutes the essence of the service. However, a question arises whether such an approach is appropriate in the case of service providers for internal clients, e.g. in large corporations, in which remuneration in the strict sense between organizational units often does not function.

8. Services as encapsulated functionalities: this view is also popular among IT service providers. The reason might be that service is perceived as a specific, closed set of functionalities for applications, processes, and elements of infrastructure coordinated with a view to supporting clients' goals.

All the above approaches complement each other and relate to different aspects of service as a phenomenon. However, the multitude of definitions makes it difficult to define what service management research should cover, and what its scope should be. This issue was so controversial that the definition formulated by Christian Grönroos - adopted in the literature - appeared only in 1990: "A service management perspective changes the general focus of management in service firms as well as manufacturing firms from the product-based utility to total utility in the customer relationship" (Grönroos, 1990, p. 7). 
The abovementioned Group for the Definition of Subdisciplines in Management Sciences indicates the thematic scopes of theoretical considerations and empirical research conducted in individual subdisciplines. As part of the management of production, services, and technology, the Group specified the following: production management; types and kinds of production; technical and organizational development; organizational methods and techniques; industrial specialization, concentration, and cooperation; sales management; life cycle design; service management; service design; shaping relationships in service management; service organization models; shaping the value of services; management under conditions of automation and robotization of operational processes.

According to the 2014 (Cyfert et al., p. 44) classification, service management covered the following areas:

- service design,

- shaping relationships in service management,

- service organization models,

- shaping the value of services.

The updated 2019 classification accurately reflects the service management context. As this article aims to show, production management preceded SM, while technology management becomes an indispensable element of organizational management, both in the context of production and services.

Thus, the purpose of this article is to explore this scope in more depth, based on the considerations of service management theorists and practitioners. Such a verification will allow scholars for a more complete definition of the position of SM in management science. The first section presented the definitions of services. The second section will examine the origins of service management. Section three scrutinizes the development of service management as a subdiscipline of management science. Section four proposes the scope of service management as a subdiscipline based on research and observation. The fifth section will consider the position of service management in the discipline of management science, mainly in the context of selected academic textbooks. Section six presents conclusions. 


\section{The Origins of Service Management}

The above definition of SM was adopted in 1990, but the research of this area has a much longer history. Grönroos, who significantly contributed to the definition of the scope of SM, describes it in opposition to scientific management (Grönroos, 1994, p. 5). It is an interesting perspective worthy of a deeper analysis. Scientific management was created as a response to the achievements of the Second Industrial Revolution (Nogalski and Rokicki, 2020, p. 39), and it supported mass production, the symbol of which was the production line. The management principles of Taylor, Adamiecki, Ford, Gantt, and Gilbreth were based on the assumptions of mass production and economies of scale. On the other hand, services at that time were more individualized. The methods of performance and effects of services such as hairdressing, shoemaking, or goldsmithery were different. The principles of scientific management did not apply to service management, and Ford's memorable dictum regarding his car Ford T - "Any customer can have a car painted any color that he wants so long as it is black" (qtd. after Debije, 2015, p. 298) - could not be employed to services. This was not a problem at a time when service establishments were small and their share in GDP was negligible. However, since the 1920s, services in the United States of America have taken the lead as the sector with the highest employment rate.

Figure 1. Changes in employment between sectors in the USA

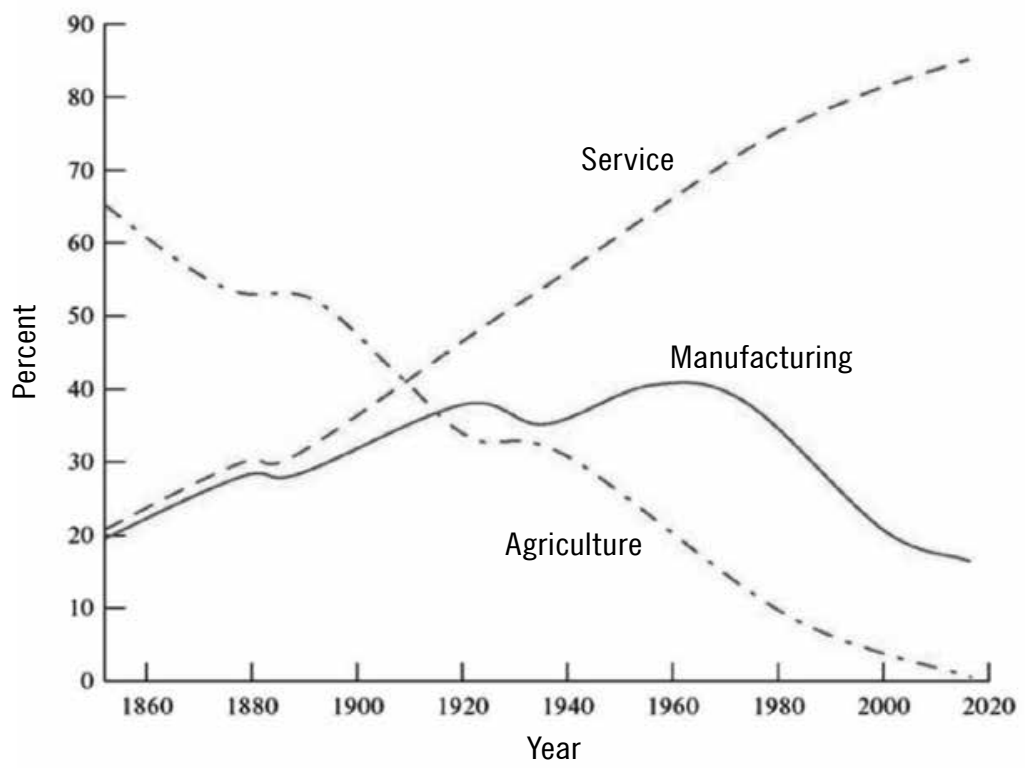

Source: Bordoloi et al. (2018, p. 7). 
There were many causes of this phenomenon. Anna Wróbel (2009, pp. 69-79) groups them in the following manner:

1. Manifestations of demographic changes:

a) Extended life expectancy, an increase in the number of elderly people, and their economic emancipation: the needs of elderly people in developed countries are largely concentrated around services - medical, paramedical, touristic, recreational - thus creating and deepening a market niche;

b) Increased level of education of the society and urbanization processes: cultural and gastronomic services become intertwined with the urban lifestyle; demand for them (especially the former ones) rises along with the education level of the society.

2. Social changes resulting in an increased demand for services:

a) Increased economic activity of women: this causes more interest in childcare services (kindergartens, daycare) and contributes to the creation of demand for other services (by increasing household income);

b) Civilizational development and the humanization and intellectualization of human life: these aspects develop needs for services in the field of education, culture, and leisure time management; a complex network of connections is created in which people become dependent on services offered by other entities.

3. Economic changes:

a) Globalization of the world economy: services in the fields of transport, tourism, and information flow, but also legal, financial, and especially, IT services. As Wróbel emphasizes (2009, p. 72), a feedback loop is at play here: the more pervasive globalization becomes, the more services appear, and vice versa. Services in the IT field are the best example here. Globalization makes access to these services easier and not limited to the country from which the given service is delivered. On the other hand, these services - such as social networking platforms or web hosting - provide users from many different locations access to the same content. Service sector companies took advantage of globalization processes to expand their business, and globalization may be deepened even further through international service development.

b) Activities of companies producing tangible goods, focusing on activities considered basic, and outsourcing other activities - most often services - to external specialists: outsourcing companies can use economies of scale and offer services at much cheaper rates, thus contributing to the development of these services. 
c) Increase in the wealth of the society: along with the increase in wealth, needs change, and services that satisfy the needs of a lower order become basic services.

d) The rapid development of technology, mainly information technology: as Wróbel indicates (2009, p. 76), contemporary technological progress used to be consumed primarily by the production of goods. Today, a different tendency becomes evident when the new waves of technologies more strongly impact the functioning of services. The example that the author offers comes from the banking sector, in which the development of automatic systems for the search, collection, and processing of information, new systems of operations, and communication increased the efficiency and quality of existing services and brought about the creation of new ones. We may thus conclude that the technology that significantly revolutionized services was the transmission of digital data packets via the Internet. The Internet has not only created a new sector of IT service providers such as Google or Facebook, but it has changed how services are provided in other sectors, such as banking or telecommunications. Moreover, the Internet also changed how companies producing goods operate, e.g. through a different approach to sales and marketing.

4. Political and legal changes:

a) Privatization in the service sector: the 1980s and 1990s were a period of privatization in both developed and developing countries. This process mainly concerned telecommunications services, rail transport, and postal services. The increased competition resulted in (according to the author) a fuller satisfaction of customer's needs through greater availability of services for consumers, expansion of product range, and higher quality accompanied by lower prices of services (Wróbel, 2009, p. 78).

b) Processes of deregulation that reduce the degree of state interference: as their importance increases, service enterprises may pressurize governments to create favorable conditions for them.

c) Processes of economic integration: integration processes within entities like the EU and the creation of free trade zones result in the enlargement of markets. In turn, this increases the scale of service provision.

If the origins of management science are related to the management of the production of goods, then the question arises as to how these teachings relate to the creation of intangible assets. This question is important because the method of management may be completely different than that described in the literature of classical scientific management. 
Grönroos lists the following differences:

Table 2. Differences between scientific management and service management

\section{Scientific management}

Focus on increasing internal efficiency: product and effort standardization

Focus on cost reduction and economies of scale, along with the specialization and division of labor

Quality management is perceived at best as an additional task

Employee training as an administrative task

\section{Service management}

Focus on meeting customer expectations: observing the market and its expectations

Introduction of an integrated approach, which is meant to develop long-term cooperation with customers (market economy, not economies of scale)

Quality management is integrated with all the other activities

Employee training as an activity embedded in company strategy

Source: Grönroos (1994, pp. 7-14).

The increasing role of services in the economy has created the need to manage them. However, service management represents a different perspective for management and quality sciences than classical production management. Both practitioners and researchers reached this conclusion gradually.

\section{The Development of Service Management as a Subdiscipline of Management}

The development of SM as a subdiscipline (and currently a dimension of subdiscipline) can be divided into several stages. The following division has been inspired by Janelle Heineke and Mark Davis (2006, pp. 369-372), but it was extended for the purposes of this article:

1. The 1950s and the 1960s: Recognition of Services as a Subject of Scientific

\section{Interest}

The interest in services first emerged from economic science. From this perspective, services were called the third sector (the first was agriculture, the second one industry/production; Johnston, 2012, p. 1). In 1968, Victor Fuchs introduced the concept of "service economy" (Fuchs, 1968, p. xxiii), highlighting the growing importance of this sector. 


\section{The First Decade, the 1970s: Identification as a Subdiscipline}

In 1972, an article appeared in the Harvard Business Review entitled "Production-Line Approach to Services." It was written by Theodore Levitt. It is important in the sense that the author was a well-known management theorist, and it was the first publication on the topic. The theses of the article were as follows:

- Services extend beyond the so-called third sector and include activities that complement industrial production.

- Service management is different from production management. Services are highly personalized, delivered in a variety of ways and under varying conditions. The human factor is important as services are offered to people by people. Production management happens in a strictly defined place (factory), processes are centralized, conditions are strictly controlled with the planned quality of products in mind. This is not the case with service and there is a clear dichotomy here.

- Service management should benefit from the legacy of production management to achieve economies of scale. In other words, it should use a specific production line. Levitt cites the McDonald's fast-food restaurant chain as an example: a factory-like food service company with strictly planned processes, uniform quality, and high standardization. A human performing the service has been reduced to an element of the process.

Four years later, Levitt developed his thesis in the article "The Industrialization of Service." According to him, the "industrialization of services" makes it possible to manage them. He notices the need to use processes that would standardize the results of service activities on a larger scale. Moreover, he aptly indicates that customers do not buy goods but a solution to the problem at hand. The latter claim was developed over the next two decades and remains valid to this day.

The "industrialization of services" means that their management is also treated as an increase in their efficiency. This perspective is often called "operations management," and it constitutes the equivalent of production management in the environment of service providers (Johnston, 1994, pp. 51-52). In the 1970s, SM was viewed through the prism of operations management.

During this period, there emerged concepts fundamental for SM. In his article "Match Supply and Demand in Service Industries," Sasser (1976) describes the processes of demand management and capacity management as the most important aspects of service management. He considers decisions made in these processes as strategic for the organization, adding a strategy layer to service management. 
In 1978, Sasser, Olsen, and Wyckoff publish the first academic book in this field, entitled Management of Service Operations: Text, Cases, and Readings. It was not a textbook yet, but rather a set of short articles supported by detailed case studies. The authors introduce the term of a "service concept," denoting a set of goods and services offered to customers (Sasser, Olsen and Wyckoff, 1978, p. 14), but also that of a "service delivery system," which the authors understand as the process of simultaneous product creation and delivery. As part of the delivery, they indicate the need to manage the service level, which is to be agreed upon between the supplier and the consumer (p. 177). They emphasize the need to design services before delivering them by means of this system (pp. 74, 78). Despite all that, Sasser, Olsen, and Wyckoff consider service as yet another product because they are influenced by the legacy of management using the production environment as a research ground.

The first decade marked the emergence of service management as a research area and the creation of basic concepts used both in theory and practice. Services became the focus of management and quality sciences but were not yet a separate subdiscipline.

\section{The Second Decade, the 1980s: Institutionalization}

In the first decade, discussions about SM were conducted primarily in the United States of America (mainly at Harvard University). In the second decade, scientists from Europe entered the debate, especially scholars from Scandinavia.

In 1982, the first service management textbook was published, namely Service Operations Management by James A. Fitzsimmons and Robert S. Sullivan. That book employs and defines the term "service package," which was used by practitioners (ITIL, Service Strategy, p. 98). There appear chapters devoted to information systems management, forecasting, resource, quality, and project management - but also to organizational culture. From the perspective of a twenty-first-century reader, the selection of topics may occasionally be surprising, e.g. the mapping of delivery vehicles' routes (Fitzsimmons and Sullivan, 1982, p. 312). However, at that time, the scope of service management (or operational management) was not clear just yet.

Two years later, the first textbook whose name included the words "service management" appeared. It was entitled Service Management: Strategy and Leadership in Service Business. In the publication, the author, Richard Normann, stresses the necessity of managing customers. He believes that the client of a hairdressing salon or a bank is more than just a client, he is a participant in a process, and that each element of the process should be managed. Relations with customers are one of the most important resources of the com- 
pany (Normann, 1984, p. 19); they should be treated individually, and it is from their viewpoint that the offer should be created. However, Normann is not the first to recognize the importance of the customer in SM. A year earlier, an article "The Customer Contact Approach to Services: Theoretical Bases and Practical Extensions" by Richard Chase appeared in Operations Research. It is considered one of the first articles to recognize the role of customers in providing services (Heineke and Davis, 2006, p. 370).

Prioritizing customer needs represents an approach radically different from Ford's, and completely unaddressed by Taylor and other major scientific management theorists. It also differs from the approach of the previous decade. While in the 1970s, there happened a reduction in the importance of the human factor as unpredictable and less controllable, in the 1980s its value began to be recognized again. Service management has been enriched by the achievements of marketing, customer behavior, and human resource management studies (Johnston, 1994, p. 56).

Heineke and Davis state that in the 1980s the quality management movement also influenced the development of the SM subdiscipline (Heineke and Davis, 2006, p. 370). We may conclude that quality management has enriched service management by endowing service delivery with a certain rigor. In management science, meeting certain quality standards and using them for quality measurement is a sign of the effectiveness of conducted activities. The ability to control services seemed necessary to legitimize them as a subdiscipline of management.

The 1980s marked the end of the stage of creating the SM's conceptual apparatus (one of the most important was "service encounter," i.e. the moment when the supplier interacts with the customer; Lariviére et al., 2017, p. 2) and, at the same time, the institutionalization and consolidation of SM as a subdiscipline. According to Evert Gummesson, in the 1980s service management acquired its identity and became the driving force for management practitioners (Gummesson, 1994, p. 94).

\section{The Third Decade, the 1990s: Stagnation in Development}

Despite the apparent progress in SM research, the vast majority of scientific publications on operational management (production or provision of services) concerned the environment of goods production (Machuca et al., 2006, p. 600). The greatest achievement of the third decade was increasing the interest in the strategic aspect. In the third decade, authors who partook in defining SM, such as Sasser or Heskett, wrote about the role of SM in organizational success. On the other hand, Johnston indicates that SM plays a role not only in the 
implementation of company strategy but also in its formulation, and so consequently - also in gaining a competitive advantage by that organization (Johnston, 1994, p. 52). Thus, there emerged an awareness that understanding the nature of services can support strategic management.

In retrospect, we may assess that after defining and institutionalizing the subdiscipline, the 1990s brought a certain slowdown. A new impetus for further development was needed.

\section{The Fourth Decade, the 2000s: A New Paradigm}

This new impetus came from the works of Stephen Vargo and Robert Lusch. In 2004, they published the article "Evolving to a New Dominant Logic for Marketing." It turned out to be the most cited Journal of Marketing title of the decade and the third most cited marketing article in history (Cantone et al., 2019, pp. 675-676). It introduced the concept of service-dominant logic (SDL) and contrasted it with goods-dominant logic (GDL). According to GDL, durable goods are the basis of economic exchange, and services are only a certain variant of goods. In line with the GDL logic, the value that participants gain in that process is the value resulting from the exchange of goods (services) for remuneration; also called value in exchange. All the considerations of SM thus far could be subsumed under the principles of this logic. In SDL, value is co-created, thus becoming value in use. The division into supplier and customer is not so clear because the customer becomes a co-creator of value (Vargo and Lusch, 2006, pp. 43-44). There is no value until it is realized, and the customer is the only party that determines whether or not the value has been achieved. Therefore, value cannot be included in the process of producing goods, and services become the prime means for creating value. The customer becomes the axis of value creation and the creation process itself takes place as a result of the relationship between its participants. Hence the growing importance of managing these relationships. This view is also relevant in the context of the economy. Service is no longer a unit of exchange but the basis of the economy (Vargo and Lusch, 2016, p. 6). The 2004 article by Vargo and Lusch highlights three facts:

a) a turn from business performance (the output is the goods produced) to processes (e.g. delivering a service, creating value);

b) service theory is applicable to various fields of science;

c) what matters for the economy is not production itself but the (co-)creation of value.

Especially this last point has implications for management science. For the classics of management, production processes were the gist of this field. By 
extending this view to SM, the subject of research would be the efficiency of operations. However, if we adopted the tenets of SDL, this view would become obsolete. The subject of research is a system of services (service management/ delivery system) understood as a dynamic configuration of an organization's resources (including people, information, technology), created to co-create value (Maglio et al., 2009, p. 399). The service is a joint product of two parties: one that uses its competences, and another that integrates the obtained competences with its resources (co-creating value) and determines value. These two parties are essentially two service systems. Thus, the co-creation of service value takes place through the interactions of service systems, and these systems are linked by value proposition. These interactions consist of three elements:

a) a proposition to co-create value for another system;

b) an agreement to the proposition;

c) the realization of the proposition: realization of value.

This approach very well explains the phenomenon of network management, along with the resource-oriented approach to management. The theory that determines SM and constitutes its starting point is the systems theory, whereby the system and the relationships between the systems are managed in order to co-create value.

The concept of value co-creation continues to be a reference point for research and analysis within the SM domain. Kazimierz Rogoziński (2018, p. 145) states that SDL oversimplifies the meaning of service management by reducing it only to managing relations yet adding nothing new to what SM really is. According to him, SDL can be explained as follows: value is co-created as a consequence of a relationship and, therefore, a service is created. It is a service because it is intangible, and what is intangible is not a good (product) but a service. Service-dominant logic may help us to understand value more - but not necessarily the service itself. Rogoziński argues that SDL cannot be studied without criticism.

However, a recent quantitative research on value co-creation conducted by Jolanta Mazur and Piotr Zaborek highlights that it is "not just a short-lived marketing fad[,] and [it] can contribute to the firm's competitive advantage by leading to meaningful operational and financial benefits" (Mazur, Zaborek, 2019, p. 548).

Moreover, SDL and value co-creation found application in the practice of IT service management (e.g. ITIL best practices; Nissen, 2019) and remains relevant to this day.

As mentioned above, the work of Vargo and Lusch became the impetus for the further development of the subdiscipline of SM. In 2006, in "A Research 
Manifesto for Services Science," Henry Chesbrough and Jim Spohrer notice that research on services happens in silos (e.g. management, marketing, technology) and called on scientists and practitioners to engage in interdisciplinary cooperation in the hope to deepen knowledge about services (Chesbrough and Spohrer, 2006, p. 35). The answer to the manifesto was the authentic cooperation between academia and business. An important discovery was that service companies themselves were interested in the development of service management as a scientific discipline. A good example is IBM, which has brought together academics, management, and technology representatives to establish a Service Science, Management, and Engineering (SSME) framework (Zhao et al., 2009, p. 2). The SSME framework is viewed to be a multidisciplinary approach at the intersection of computer science, management science, strategy science, law, and social sciences.

The pillars of SSME include (Ng et al., 2009, pp. 3-5): co-creation of value; recognition that the customer is part of the service delivery system; understanding that customer needs are of fundamental importance; understanding that value creation in services is different from that in the production of goods (the value of a commodity is created linearly from design to production and through linear supply chains, while services often include "constellations of values" that are networked and represent the complexity of the modern world).

In the first decade of the twenty-first century - and the fourth decade in the development of SM - many manufacturing companies defined their profile as service-based, including IBM, Rolls-Royce, BT (formerly British Telecom), HP (Ng et al., 2009, p. 19). The approach that states service complements product value was replaced by the view that service is what a company offers, and product is delivered in a service package. This trend is confirmed by recent publications (eg. Kanovska, 2020, p. 105).

The greatest achievement of the fourth decade was certainly the agreement regarding the subject of SM.

\section{The Fifth Decade, the 2010s: Automation}

Service automation was a progressive phenomenon, but in the fifth decade of the SM subdiscipline's development, it became one of the main research topics. Of course, automation is associated with the extensive use of digital technologies, which have increased the range and scope of solutions offered by businesses (Demirkan and Spohrer, 2018, p. 8). According to some authors (Cyrek, 2005, p. 282), services developed mainly under the influence of information and communication technologies. These technologies have made value co-crea- 
tion processes more flexible, created new resource configurations for service packages, reduced costs, increased efficiency, and improved customer experience. According to Martin Matzner and Marion Büttgen (2018, p. 7), the impact of technology on the field of SM can be observed on:

- the macro level: the digital transformation resulted in the emergence of new players who could enter markets of traditional service providers thanks to widely spread Internet access (e.g. Uber, Airbnb, Amazon); network orchestration increases, and there emerge ecosystems that connect companies and customers in value chains; technology offers companies an opportunity to expand the portfolio of offered services (e.g. hosting as "storage as a service;" access to software as "software as a service");

- the micro level: technology changes the nature and way of performing tasks in SM. Many processes are being automated; automation and cognitive systems are considered a condition for increasing the productivity and quality of services provided (Keller, 2017, p. 884).

Benkenstein describes three waves in the digital transformation of services (Benkenstein et al., 2017, p. 13), which also constitute a research area for SM:

a) wave 1: technology is an instrument used to automate individual activities within service systems;

b) wave 2: technology is a factor that coordinates and replaces groups of processes in the system;

b) wave 3: technology becomes a service/product.

Matzner and Büttgen classify artificial intelligence, robotics, and blockchain as the technologies that drive most change in service management. Other authors also include big data and cloud computing (Nogalski and Rokicki, 2020, p. 36), along with social networks (Dziwulski and Ogrzebacz, 2017, p. 96).

Digital transformation supports servitization (increasing the role of the service sector), and vice versa. Its effect is the expansion of co-created values and the automation of service systems. The aspects of interactions between technology and management have become a field for researchers and the key to the functioning of SM. The Table 3 summarizes the considerations of section three. 
Table 3. Development of service management as a subdiscipline of organizational sciences and management

\section{Decade in the development of the subdiscipline}

1. 1970 s

2. $1980 \mathrm{~s}$

3. $1990 \mathrm{~s}$

4. 2000s

5. $2010 \mathrm{~s}$
Decade-defining term

Identification

of research area

Institutionalization of service management as a subdiscipline of management science

Stagnation in the development of service management as a subdiscipline of management science

Defining the subject of service management as a subdiscipline of management science

Automation of service management as a new research area
Most important phenomena

The statement that services can be managed if they observe the principles of production management. The human factor should be subject to the processes of ensuring effectiveness. Basic concepts: "service concept"; "service system"; "service capacity"; "service levels".

The scope of service management extends beyond operations management by recognizing the importance of customer relationships and the role of employees in delivering services. Defining an apparatus for conceptual service management.

Acknowledging the strategic dimension of service management. The growing importance of technology in service delivery.

Consensus about the subject of research in service management (co-creation of value through enterprise service management systems) and the role of goods-service relationship in value creation.

Acknowledging the importance of the development of digital technologies for the provision of services. Recognizing the role of technology as a determinant in effective service management.

Source: own elaboration.

It is clearly visible that the creation of theoretical concepts in SM was secondary to the appearance of the phenomenon itself. If services became the dominant sector in the US economy as early as in the 1920s, the question arises as to why the corresponding subdiscipline of management appeared only half a century later. Richard Metters and Ann Marucheck took it upon themselves to answer that question. They listed five reasons why service management research was, as they said, "neglected" (Metters and Marucheck, 2007, p. 201). These reasons are:

1. Difficulties in defining services. This problem - or rather the multifaceted nature of the phenomenon - was discussed in the first chapter. According to the 
authors, the core of the definition-related issue in the field of management was whether services should be treated as a branch of the economy or as a set of processes. As a branch of the economy, services are often included in governmental statistics, in which for the purposes of calculating GDP, they are often classified as anything that is neither agriculture nor industry. In accordance with this perception, the finance department in a manufacturing company represents industry as a sector of the economy. However, from a procedural point of view, the finance department would be a service. The process-oriented approach is not new. In 1870, Fred Harvey created a process for delivering meals from restaurants to rail passengers at stations. Passengers could order meals by means of the latest technology: the telegraph. For Harvey, service and production both can be managed as a process in a standardized and systematic manner. Other definitions attempted to describe services as activities with a corresponding user input or conducive to the production of intangible objects. As the authors emphasize, even now there is no consensus about what services actually are. Even though the process-oriented approach seems to have gained the most popularity, the question of what the subject of management was valid for many years, as we described in this chapter.

2. The perception of services as not contributing much to economic growth and not worthy of a deeper reflection. The postulate that services are something "inferior" to production and agriculture was already put forward by Adam Smith. He believed that services are "unproductive," as opposed to industry and agriculture that are "productive." Marxism-Leninism also treated services in a similar way. According to this doctrine, services inhibited economic development (Marginson, 1998, p. 573). Back in the 1960s, Nicholas Kaldor, an economic adviser to the British government, wrote that there is a link between economic growth and industrial production that does not exist in the case of services, and therefore governments should create incentives for workers to move to the industrial and agricultural sectors (Matters and Marucheck, 2007, p. 202). However, with the increase in the share of services in the economy, these views became obsolete.

3. The past views of managers stating that services do not contain processes. The authors cite the opinion that the process must be repeatable. You cannot apply Taylor's scientific management to an activity that is performed only once. In the past, services were performed in close proximity to the recipient. The prevailing view was that service is different with each execution, so there is no repetition. If there is no repeatability, there can be no mention of a process either. According to the authors, it was supposed to be quite a typical view among managers in the past. The technological changes triggered by the Third 
Industrial Revolution proved this view invalid. Currently, there are many standard services, in which properly designed processes are performed, and recipients can be located anywhere in the world.

4. Service companies used to be relatively small. The authors use the example of restaurants. In 1950, the largest chain had 180 restaurants, and in 2007, more than 30,000 (McDonald's). The benefits gained through the standardization of processes are visible in their multiple replications.

5. No possibility of standardization. What distinguished services from the production of goods was the presence of the recipient in the process. When creating a service, the question arose as to what the customer's contribution should be. The bigger it is, the more difficult the service becomes to manage. Only the massification of service companies and the development of technology made client' participation more predictable and manageable.

\section{The Scope of Service Management as a Scientific Subdiscipline}

Services can be studied from different perspectives, and management and quality science are just one of them. This broader context cannot be ignored when specifying the scope of service management as a subdiscipline of management (or a dimension of the subdiscipline). Therefore, let us look at how the so-called service science - whose formalization was initiated by the Chesbrough and Spohrer's manifesto - defines service management, and we will verify whether this approach will help us redefine the scope of service management from the viewpoint of management and quality science.

As mentioned in section three, the 2000s saw intense activity aimed at integrating various research approaches. The purpose of these activities was to define what service science was to undertake. According to Jim Spohrer, service science deals with the evolution, design, and management of service systems (Pavlov and Hoy, 2018, p. 110). In this spirit, Claudio Pinhanez and Paul Kontogiorgis suggested in 2008 a discipline classification under service science. The service science was to include the following disciplines: services foundations, service engineering, service management, human aspects of services, service design, service arts. Service management would consist of the "subdisciplines" gathered in the Table 4. 
Table 4. Classification of disciplines in service science and their possible inclusion in service management

\begin{tabular}{l|l} 
Service Marketing & $\begin{array}{l}\text { Marketing research in the context of service management (especially value } \\
\text { creation in supplier-customer relationships) }\end{array}$ \\
\hline Service Operations & $\begin{array}{l}\text { Processes and procedures necessary to deliver a service; approaching } \\
\text { the issue from the business, not the technical side }\end{array}$ \\
\hline Service Management & $\begin{array}{l}\text { Application of management science and practices to the service } \\
\text { environment }\end{array}$ \\
\hline Service Life Cycle & $\begin{array}{l}\text { Research on characteristics of service life cycle as opposed to the life cycle } \\
\text { of material goods }\end{array}$ \\
\hline $\begin{array}{l}\text { Service Innovation } \\
\text { Management }\end{array}$ & $\begin{array}{l}\text { Research on innovations in services, in particular the requirements } \\
\text { for creating new results, processes or procedures of the service } \\
\text { management system that would support innovation }\end{array}$ \\
\hline Service Quality & $\begin{array}{l}\text { Quality perception and measurement, methods, and processes of service } \\
\text { quality control }\end{array}$ \\
\hline $\begin{array}{l}\text { Human Resources } \\
\text { Management }\end{array}$ & $\begin{array}{l}\text { Processes and procedures of human factor management in services } \\
\text { from the viewpoint its impact on service delivery }\end{array}$ \\
\hline $\begin{array}{l}\text { Customer Relationship } \\
\text { Management }\end{array}$ & $\begin{array}{l}\text { Processes and tools used by the service provider to create and maintain } \\
\text { relationships with and value for customers }\end{array}$ \\
\hline Service Sourcing & $\begin{array}{l}\text { Outsourcing and offshoring in services, contract management, "make } \\
\text { or buy" decisions, service level agreements, online markets, sourcing } \\
\text { structures }\end{array}$ \\
\hline $\begin{array}{l}\text { Services Law } \\
\text { Globalization }\end{array}$ & $\begin{array}{l}\text { pontract-related issues, legal framework, state regulations, intellectual } \\
\text { property protection, and patents in the service environment }\end{array}$ \\
\hline management
\end{tabular}

Source: Pinhanez and Kontogiorgis (2008, p. 4-5).

In 2009, Jim Spohrer suggested the following subdisciplines of the modified version of SSME, known as SSMED: Service Science, Management, Engineering, and Design (Spohrer, 2009, pp. 9-18):

- marketing: issues related to understanding customer needs and ensuring the quality of the solutions offered;

- operations: design, management, and enhancement of a system that offers services;

- governance: principles governing the system offering services and compliance with standards; 
- design: making sure that the delivered services offer the customer the best possible experience;

- anthropology: issues related to human resources and people's access to resources;

- engineering (transformation of knowledge into value by transferring knowledge in a tangible and useful way; Spohrer, 2009, p. 15): issues related to creating an offer for customers (value proposition);

- computing: understanding the importance of computer systems and their use for offering services;

- sourcing: identifying and acquiring necessary resources, including legal issues;

- strategy and management: including management of information systems, projects, innovations, finance, supply chain, resources, business relationships, human resources, intellectual property, contracts, risk, strategy, and organizational change.

For Spohrer, the proposed scope of SSMED is to mean an approach that integrates various fields of science to create a new service-related discipline with clearly defined boundaries (Spohrer, 2009, p. 1). Although the author tries to present this scientific discipline as a relationship between management, technology, and design, all the subdisciplines presented have a strong relationship with management, and as such could constitute an extended scope of SM.

On the other hand, Lofgren, Pavlov, and Hoy describe the structure of a service management system by specifying its ten components. This structure also provides directions for defining the scope of its components, as presented in the Table 5.

\section{Table 5. The structure of the service system}

No. Component

1 Resources

2 Access rights

3 Units

4 Stakeholders

5 Co-creating value

\section{Description}

Everything that can be used to produce services: people, technology, financial resources, etc.

Access control to resources that can be borrowed, shared, or subject to exclusive or privileged access.

Resource configurations capable of creating value in service manufacturing systems.

Parties interested in aspects of the service, most often customers, suppliers, authorities, competitors.

It occurs through collective action of stakeholders. 


\begin{tabular}{|c|l|l|}
\hline 6 & Networks & Patterns of interaction between systems, services, and system units. \\
\hline 7 & Environment & Details of service systems and units in systems. \\
\hline 8 & Governance & $\begin{array}{l}\text { Formal and informal mechanisms for driving service systems to meet } \\
\text { requirements. }\end{array}$ \\
\hline 9 & Outcomes & Activities within service systems leading to value creation. \\
\hline 10 & Measurements & Measuring results (quality, productivity, compliance, sustainable innovations). \\
\hline
\end{tabular}

Source: Lofgren et al. (2019, p. 56).

It is a good idea to supplement the above areas of interest in service management as a subdiscipline of management with concepts developed in management practice.

The consulting company Proacteur has collated its experiences in the field of service management into the article entitled "Service Management 3.0 - the next generation of service." According to the authors, there are four prime aspects of service management (Andersen and Ankerstjerne, 2014, p. 3):

1. service culture;

2. employee engagement;

3. service quality;

4. customer experience.

The best practices of ITIL for IT service management are also widely discussed in the literature (Shrestha et al., 2016; Cronholm et al., 2017; Eikebrokk et al., 2017). So far, four versions of ITIL were released. The third version, updated in 2011, divides the scope into five phases:

1. service strategy: the management of strategy, finance, demand, service portfolio, and business relationships;

2. service design: the coordination of design (project management), service catalog, availability, capacity, continuity, information security, service levels, and suppliers;

3. service transition: planning (project management), the management of configuration and assets, change, implementation, testing, and knowledge;

4. service operations: the management of events, access, incidents, problems, and fulfillment of requests.

5. continuous service improvement. 
The third version is the most ordered one, and it reflects the life cycle approach. It consists of processes with a fairly complex structure. From the researcher's viewpoint, it can be helpful for a deeper exploration of the selected phase or issue.

The fourth version of ITIL has divided the scope of service management into three categories:

1. General management practices: strategy management, portfolio management, architecture management, service financial management, workforce and talent management, continual improvement, measurement and reporting, risk management, information security management, knowledge management, organizational change management, project management, relationship management, supplier management;

2. Service management practices: business analysis, service catalog management, service design, service level management, availability management, capacity and performance management, service continuity management, monitoring and event management, service desk, incident management, service request management, problem management, release management, change enablement, service validation and testing, service configuration management, IT asset management;

3. Technical management practices: deployment management, infrastructure and platform management, software development and management.

The fourth version of ITIL offers a more integrating approach to IT service management, assuming that individual processes (called practices in the fourth version) are not used in sequence - but in parallel. This agrees with the principles of agile management.

Over the years, a plethora of SM textbooks appeared. To determine the scope of SM, we analyze the contents of some of these textbooks below, including the most classic ones. The examined titles are:

- 1978: Sasser, W., R. Olsen and D. Wyckoff. Management of Service Operations: Text, Cases and Readings, Boston: Allyn and Bacon;

- 1982: Fitzsimmons, J. and R. Sullivan. Service Operations Management, New York: McGraw-Hill;

- 1984: Normann, R. Service Management: Strategy and Leadership in Service Business, Wiley;

- 1988: Muhlemann, A., J. Oakland and K. Lockyer. Production and Operations Management, FT Prentice Hall; 
- 1990: Heskett, J., W.E. Sasser and C. Hart. Service Breakthroughs: Changing the Rules of the Game, Toronto: Macmillan;

- 2000: Grönroos, C. Service Management and Marketing: A Customer Relationship Management Approach, Chichester: Wiley;

- 2003: Van Looy, B., P. Gemmel and R. Van Dierdonck. Services Management: An Integrated Approach, FT Prentice Hall;

- 2008: Johnston, R., and G. Clark. Service Operations Management: Improving Service Delivery, FT Prentice Hall;

- 2018: Bordoloi, S., J. Fitzsimmons and M. Fitzsimmons. Service Management: Operations, Strategy, Information Technology, London: McGraw Hill.

The Table 6 summarizes the most important subject areas that the textbook deals with in explaining issues related to SM. These areas have been presented according to the frequency of their occurrence as the headings of sections or subsections. Each year corresponds to the date of publication.

Table 6. Thematic areas of selected service management manuals

\begin{tabular}{|c|c|c|c|c|c|c|c|c|c|}
\hline Area of interest & 1978 & 1982 & 1984 & 1988 & 1990 & 2000 & 2003 & 2008 & 2018 \\
\hline $\begin{array}{l}\text { Service quality (measuring, } \\
\text { controlling) }\end{array}$ & & $x$ & $x$ & $x$ & $x$ & $x$ & $x$ & $x$ & $x$ \\
\hline $\begin{array}{l}\text { Service environment - } \\
\text { characteristics }\end{array}$ & $x$ & $x$ & $x$ & & & $x$ & $x$ & $x$ & $x$ \\
\hline $\begin{array}{l}\text { Service concept / package / } \\
\text { bundle }\end{array}$ & $x$ & $x$ & $x$ & & & $x$ & $x$ & $x$ & $x$ \\
\hline $\begin{array}{l}\text { Service (and/or service } \\
\text { system) design }\end{array}$ & $x$ & $x$ & & $x$ & $\mathrm{x}$ & & $x$ & & $x$ \\
\hline Service strategy & & & $x$ & $x$ & $x$ & & $x$ & $x$ & $x$ \\
\hline $\begin{array}{l}\text { Financial management, } \\
\text { prices }\end{array}$ & $x$ & $\mathrm{x}$ & $x$ & $x$ & & $x$ & $x$ & & \\
\hline $\begin{array}{l}\text { Demand and capacity } \\
\text { management }\end{array}$ & $x$ & $x$ & & & $x$ & & $x$ & & $x$ \\
\hline $\begin{array}{l}\text { IT system and technology } \\
\text { management }\end{array}$ & & $x$ & $x$ & & $x$ & & $x$ & $x$ & \\
\hline $\begin{array}{l}\text { Managing employees } \\
\text { in services }\end{array}$ & & & $x$ & $x$ & $x$ & & $x$ & $x$ & \\
\hline $\begin{array}{l}\text { Customer relationship } \\
\text { management }\end{array}$ & & & $x$ & & $x$ & $x$ & $x$ & $x$ & \\
\hline
\end{tabular}




\begin{tabular}{|c|c|c|c|c|c|c|c|c|c|}
\hline $\begin{array}{l}\text { Globalization, international } \\
\text { management, network } \\
\text { management }\end{array}$ & & & $x$ & & $x$ & $x$ & $x$ & & $x$ \\
\hline Marketing, branding & & & $x$ & $x$ & & $x$ & $x$ & $x$ & \\
\hline $\begin{array}{l}\text { Service management / } \\
\text { delivery system }\end{array}$ & $x$ & $x$ & $x$ & & $x$ & & & & \\
\hline Service culture & & $x$ & $x$ & & & $x$ & & $x$ & \\
\hline $\begin{array}{l}\text { Managing innovation } \\
\text { in services }\end{array}$ & & & $\mathrm{x}$ & & & & $x$ & $\mathrm{x}$ & $\mathrm{x}$ \\
\hline $\begin{array}{l}\text { Location and management } \\
\text { of the workplace }\end{array}$ & & $x$ & & $x$ & & & $x$ & & $x$ \\
\hline Customer expectations & & & & & $x$ & $x$ & $x$ & $x$ & \\
\hline Service-level management & $x$ & & & & & & $x$ & $x$ & \\
\hline $\begin{array}{l}\text { Resource and inventory } \\
\text { management }\end{array}$ & & $x$ & & $x$ & & & & & $\mathrm{x}$ \\
\hline Queues, modeling queues & & $x$ & & & & & & $x$ & $x$ \\
\hline $\begin{array}{l}\text { Service transformation, } \\
\text { change management, } \\
\text { project management }\end{array}$ & & $x$ & $x$ & & & & & & $x$ \\
\hline Supplier management & & & & & $x$ & & & $x$ & $x$ \\
\hline $\begin{array}{l}\text { Process management } \\
\text { in services }\end{array}$ & & & & $x$ & & & & $\mathrm{x}$ & $x$ \\
\hline Forecasting & & $x$ & & $x$ & & & & & $x$ \\
\hline $\begin{array}{l}\text { Leadership, decision } \\
\text { models }\end{array}$ & & $x$ & $x$ & & & & & & \\
\hline Service improvement & & & & & & & & $x$ & $x$ \\
\hline Service encounter & & & $\mathrm{x}$ & & & & & & $x$ \\
\hline (Co-)creation of value & & & $x$ & & & & & & \\
\hline Service dominant logic & & & & & & & & & $x$ \\
\hline
\end{tabular}

Source: own elaboration.

An analysis of research, publications (including books), and the results of the activities of service management practitioners allows us to determine the scope of SM. This term was and will be conventional because various areas of interest in SM are also areas of interest not only in other management subdisciplines but also in other scientific disciplines. 
The thesis of this article is that $\mathrm{SM}$ as a subdiscipline of management science (and since 2019: as a subdiscipline dimension) should primarily explore the following areas:

1. Service environment. Studying the environment leads to an understanding of the SM context. This environment represents the context of an organization offering services and may be different from that of an organization offering goods:

a) goods versus services, and production management versus SM: similarities and differences, service-dominant logic (SDL);

b) service transformation: many companies that previously declared themselves as production companies have become service companies; this transformation may occur in a number of ways; studying service transformation will help understand this process;

c) network management, inter-organizational management: value creation happens in constellations, at the intersection of multiple service systems; value is (co-)created in a dynamic and turbulent environment in which orchestration typical of network relations is required.

2. (Co-)creation of value in services. Research into determining what value is and how it is determined from a management (not marketing) perspective:

a) managing customer expectations, creating value propositions: this area examines how customer expectations are translated into a value proposition;

b) service concept, service package, service portfolio, service encounter: the value proposition must be formalized through the basic concepts and phenomena necessary to define what the value delivered to customers is or can be; each of these concepts/phenomena can become an area of research.

c) managing communication with customers, managing relations with customers: after agreeing on the value proposition, one must properly communicate it and then manage all interactions between the organization providing services and the client.

3. Service management system. This area explores the means of service delivery. The system is made up of processes, people, and technology. They all must be managed in the context of the service environment:

a) design: designing a service and service management system; configuring resources to create a system; resource, demand, availability, and supplier management processes;

b) human resource management: engaging employees as a link between service design and performance; designing positions suitable for services; the 
selection, training, and evaluation of employees, taking into account the skills useful in services;

c) technology management in the context of services: information systems, information security, innovation; innovation in services can even be considered - regardless of a proper service system - as one of the two pillars of service science (Stoshikj et al., 2016, p. 217); it is supported by requisite technologies.

4. Service quality management. This area examines the way value is provided. It covers both traditional operations management and factors related to service culture:

a) service quality management processes: primarily service level management, measurement, control, and improvement; these processes are responsible for the proper functioning of the system, and thus for ensuring that the system creates value;

b) service culture of the organization: among other things, this category should be construed as the meaning and creation of the vision, mission, and values of the organization, its customs and standards, principles of leadership in a service organization, and methods of shaping appropriate attitudes; an organization may have the best possible processes but cultural factors must work in harmony with them.

Figure 2. Proposed scope of service management as a subdiscipline of organizational and management science

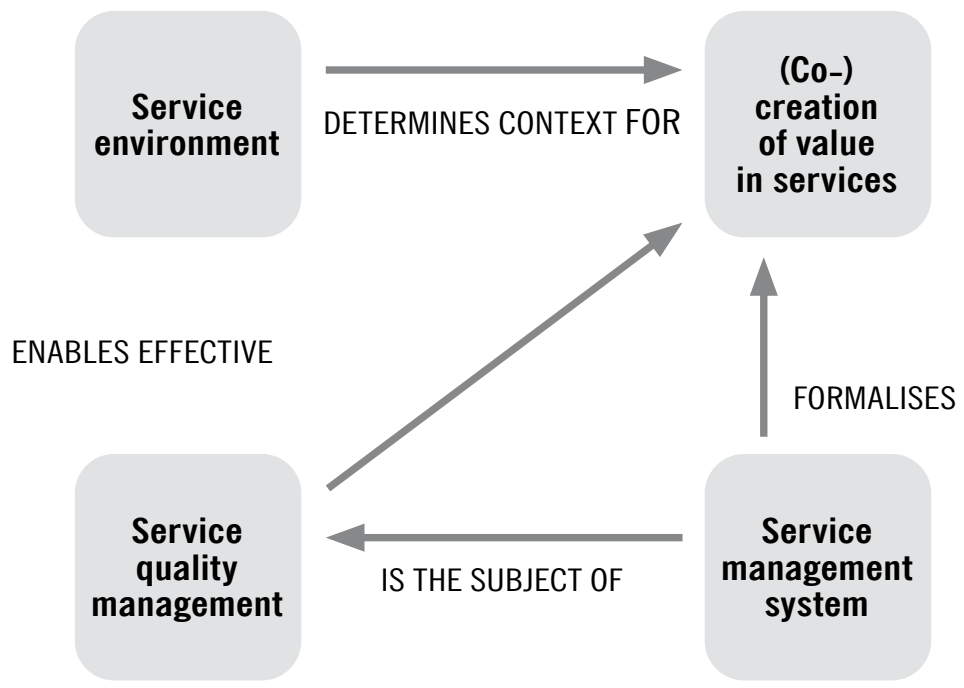

Source: own elaboration. 
The proposed scope may seem narrow. However, this is a scope that - in the structure of management science - can be best studied in the context of SM as opposed to other subdisciplines. Both the characteristics of the subdiscipline/dimension of subdiscipline, the conceptual framework, and the results obtained so far allow the best exploration of issues related to the definition, creation, monitoring, and improvement of values in the context of management. All these areas are linked by the fact (different from other subdisciplines) that services are the subject of management.

\section{The Position of Service Management in Management Science}

This part of the article focuses on reflections about the presence of the service perspective in the achievements of organization and management sciences. For this purpose, we analyze management textbooks from different time periods. The aim of this undertaking is to examine whether and how the development of SM correlates with changes in the thematic scope of these textbooks.

H. Koontz and C. O'Donnel (1955). Principles of Management: An Analysis of Managerial Functions. New York: McGraw-Hill Book Company.

This textbook was published before SM stirred the interest of researchers.

Therefore, it is no surprise that the authors state, "Neither in the literature nor in the experience of business managers can one find substantial information on the importance of service departments or on the means of measuring such importance" (p. 176). They devote one chapter to service departments, denoting auxiliary and supporting departments, such as sales, control, finance, and repair departments. Therefore, in this sense, "services" are neither a product nor a factor contributing to the achievement of competitive advantage, but only activities that help to produce goods. They are also a source of savings for the organization. In its entirety, the textbook treats services as an addition to the main activity of the enterprise. And this primarily includes operational activities, as was established by the classics of scientific management.

\section{Atkinson et al. (1986). The Manager's Handbook. London: Sphere.}

Twenty years later, service management is already the subject of research, and the field has developed a conceptual framework. As mentioned above, in the 1980 s the importance of the customer in the service delivery process was finally recognized. There is a brief chapter in this textbook on customer relations. According to the authors, these relationships should be considered when creating a marketing strategy for goods and services. From the viewpoint of the 
current sixth decade of SM development, such an approach to the role of customer relations no longer seems adequate. Relationships should not only be of interest when you develop a strategy and action plans. Customer relationship management is part of operational activity and a determinant of SM success. The outlook presented in the textbook reflects an interest in this aspect of management found in the 1980s, but also serves as proof that its research was imprecise, as the latter happened only two decades later. According to the authors, most managers consider profit, efficiency, productivity, information, and the level of sales or technical innovation to be a contributor to success, noting that customer relationships are relegated to the background (Atkinson et al., 1988, p. 94). This textbook describes planning (p. 118) and controlling (p. 120) on examples of the production of goods. There are also chapters on production management and production strategy (pp. 122-125); however, there is no further direct reference to services.

L. Megginson, D. Mosley and P. Pietri (1989). Management: Concepts and Applications. New York: Harper \& Row.

The authors believe that there is a tremendous increase in the importance of services in the economy (p. 642). However, they indicate that this increase is especially noticeable in low-wage sectors (gastronomy, care, beauty services), which are not of interest to specialized personnel and do not create technological changes that would increase productivity. They even recognize that one of the reasons for the decline in productivity is the servitization of the economy ("shift to services;" p. 641). These theses may seem controversial also because - from the perspective of 2021 - we know that the consecutive technological breakthroughs happened precisely in the service sector. On the other hand, the focus on productivity points to what Vargo and Lusch called the goods-dominant logic as opposed to the service-dominant logic. When discussing operational management, Megginson, Mosley, and Pietri note that goods and services are created by systems, which is in line with the modern view. To discuss the system, they cite examples from the goods production environment because these have more unambiguous goals and are easier to explain (p. 602). This is a clear example of why service management was not studied on a par with production management for a long time. This textbook defines operations as activities that turn inputs into outputs, which is consistent with the definitions offered by SM theorists. The authors used the achievements of science from the fields of demand, capacity, resources, and design management. Due to their relative universalism, these aspects and the focus on automation of operational activities can be used to explain management from the viewpoint of services. 
Moreover, the textbook contains extensive chapters devoted to the human factor (recruitment, communication, motivation, leadership) but not in the context of value creation. Management: Concepts and Applications is an in-depth study of the science of management, which deals with topics important to SM. However, the book proposes a fundamentally wrong description and role of services.

B. Kaczmarek and C. Sikorski (1995). Podstawy zarzqdzania. Zachowania organizacyjne (The Basics of Management: Organizational Behaviours). Łódź: Absolwent.

A textbook depicting the most important aspects of organization and management sciences in the 1990s. It is so universal that it can be applied to both production and service management. Even though it fulfills its role, we should state that if the reader would like to learn about the service perspective described in chapter four as the scope of SM, such information is not provided (with some exceptions regarding human resource management).

Similar conclusions can be drawn regarding the 1995 textbook Podstawy organizacji i zarzqqdzania (Organization and Management Basics) by Monika Kostera. In the 1990s, SM went through a period of stagnation and did not provide management science with a perspective that was clear and interesting enough to be noteworthy.

J. Kisielnicki (2006). Zarzqdzanie organizacjq (Organizational Management). Warszawa: Wyższa Szkoła Handlu i Prawa.

The fresh impetus for SM as a subdiscipline of management in the 2000s' was not yet recorded by this textbook. Nevertheless, it already contains valuable chapters on organizational culture and information system management. Technological advances determine changes in the subject and scope of management science. The author recognizes this and describes examples of these changes in detail. Although Kisielnicki does not state it explicitly, this description presents the functioning of IT services, a type of services that are becoming increasingly important and are also becoming the subject of management science.

A.K. Koźmiński and D. Jemielniak (2008). Zarzqqdzanie od podstaw. Warszawa: Wydawnictwa Akademickie i Profesjonalne. In English available as: The New Principles of Management (2013). Berlin: Peter Lang Verlag.

This textbook contains a separate chapter on value creation and management. It makes liberal use of the concept of the value chain but indicates that it works best in manufacturing companies (p. 434). Moreover, the authors state that currently over $80 \%$ of employees work in services, and therefore the linear concept of the value chain must be updated. They believe that the concept of 
a network of values is more correct, understood as "a network of connections, unique for each organization ... in which there is no constant sequence of its formation, but what is important is the simultaneous influence of individual elements ... knowledge, intelligence, services, products, innovation, design and others." This concept puts stakeholders first because it assumes that organizations "are successful mostly when they are able to effectively adapt to the network of contacts that the stakeholders possess," but also employees "should be allowed as much as possible to cooperate and exchange resources within the network." The aim is to increase the value offered. According to the authors, the design and development of products begin with client expectations, and this attitude is called the customer-oriented approach (p. 322). This attitude is "an expression of a certain humility towards the needs of recipients, along with a denial of a specific arrogance of the organization in which an exaggerated belief in its own excellence and the perfection of its own products has built up. On a competitive market, arrogance is virtually a guarantee of failure." In the days of Ford, customer expectations did not matter. However, modern management has rejected this view. A transformed way of thinking about an organization is clearly reflected here.

The textbook also contains chapters on resources and processes, people and motivation, organizational culture, brand, image, and marketing, along with innovation and entrepreneurship. All these issues are akin to the scope of SM.

The book Management Matters by A.K. Koźmiński, D. Jemielniak and D. Latusek-Jurczak (2014, Warszawa: Wolters Kluwer Polska) restates the thesis contained in The New Principles of Management, but it also devotes much attention to international management. Service management currently functions in an international environment, so everyone should learn it.

M. Kostera and M. Śliwa (2010). Zarzqdzanie w XXI wieku (Management in the Twenty-First Century). Warszawa: Wydawnictwa Akademickie i Profesjonalne.

This publication represents a completely different approach to how services are treated in management textbooks. There are three chapters devoted to services, all in the context of quality management. The authors confirm that publications on the quality of services appear most often in marketing. They claim that the quality of material products can be assessed by means of objective and quantitatively measured parameters is something much more problematic with services (p. 142). The assessment of service quality considers not only the efforts of the organization itself but also the emotions evoked in the client during service provision. The textbook cites research results that claim a relationship 
between good treatment of human resources in the organization, proper treatment of customers by employees, and the improvement of customer perception of the service itself (p. 147). The importance of the relationship is strongly emphasized. That relationship is defined not by one service interaction but, instead by a series of interactions between service providers and service consumers. This also means the quality of service provided is assessed at each interaction and through the service relationship. Customers are influenced by people and organizational processes. This is demonstrated by J. Heskett's concept of the "service profit chain." According to it, an organization providing services consists of people and processes, and "high internal quality [of these processes] means that employees and managers of the service organization have good conditions to perform their professional duties, thanks to which they provide high-quality services to clients" (p. 148). This internal quality must be measured. The authors cite several methods such as the SERVQUAL or SERVPERF models, the technical or functional quality model, as well as statistical methods (pp. 153-160).

The textbook was written at the end of the fourth decade of SM development, and it extensively draws upon the research achievements of that period. It exemplifies the fact that the necessity of service management forced a different emphasis within the sciences of organization and management.

To sum up this part of the considerations, let us state that the subject of management science evolved - as represented in the above examples of textbooks - just as the subject of SM has evolved as a subdiscipline of management. The development of research in the field of marketing, strategy, and human resource management has enriched both the discussed scientific discipline and its subdiscipline. However, the view that SM influenced the shape of management science would not be justified. A more valid claim would be to say that they developed under the influence of similar phenomena and research. At this stage of our considerations, the question of the mutual relations of management and service management remains open.

\section{Discussion and Summary}

One of the leading theoreticians of SM and an extremely prolific SM studies representative of the Scandinavian school, Christian Grönroos, believes that SM is not a separate subdiscipline of management (Grönroos, 1994, p. 14). He presented this view in 1994 on the grounds that SM is not yet fully defined. We now know that this claim was valid only at that time. Service management offers a view that enriches the 
research area of management with new perspectives. One may be even tempted to say that SM is the reason why management science maintains a relatively close relationship with the world of practice. The achievements of SM "updated" the scope of management and ensured that the examined areas remain related to the changes that happen in management practice in organizations. We cannot ignore the fact that the effects of Vargo's and Lusch's studies were consumed by the standard ITIL 4 (ITIL4, pp. 8, 180), utilized as a management framework for IT companies. It is a perfect example of how the research world contributes to contemporary management practices, and in particular, how SM contributes to the development of management science.

Services are the most important sector of the economy, offering employment for the majority of the workforce in developed countries. There is an unquestionable need to manage services, hence we need service management as both a practice and a research area. Service management drew on the achievements of other disciplines and subdisciplines of management. This article refers to the classification approved by the Committee on Organizational and Management Sciences of the Polish Academy of Sciences (PAN). The initial version from 2014 positions SM as a separate subdiscipline within the organization and management sciences. In 2018-2019, changes were made to the scopes of scientific disciplines, as a result of which the new name of the discipline is management and quality science. This made necessary a fresh look at the scope and coexistence of subdisciplines. Thus, SM became incorporated into one subdiscipline along with production management and technology management. Although SM already defined itself as a separate field, this inclusion was justified. Production management is a precursor for SM, and the first SM researchers came from this very environment. The relationship with technology management is also evident. A significant number of services are now provided through technological means. At the outset of the third decade of the twenty-first century, activities at the intersection of service and technology are an area of increased activity. Therefore, scholarly attention should be directed there. This article provides many examples of the close relationship between these three domains.

In the classification of SM management subdisciplines, there are other functional-level sub-disciplines:

- Logistics management. SM relies heavily on relationships with both customers and suppliers. These are network-based relationships that require an efficient supply chain. Logistics management serves as a trigger of SM.

- Human resource management (HRM). In the case of this subdiscipline, relations can be described as symbiotic at this stage. Service management overtook the 
achievements of HRM and implements them successively. The HRM approach received a fresh impetus from SM due to slightly different expectations from employee management in a service organization. One may be tempted to say that effective SM would not be possible without good HRM. This fact and the effect of SM on HRM constitute an interesting research area worthy of deeper exploration.

- Marketing management. Customer-oriented SM borrows its outlook from the science of marketing. The conceptual framework is also partially similar; however, the goal is different. For marketing, the aim is most often a market analysis that determines the recipient's needs, along with creating and maintaining a new demand in the recipient. For SM, the purpose lies in creating value through service delivery. It can be concluded that the effects of SM are more tangible. Many researchers in the second and fourth decades of SM development came from the marketing community, and it was they who contributed greatly to delineating the scope of SM.

- Financial management of the enterprise and management accounting. In the SM textbooks analyzed above, financial management often recurs as a subject of SM. Financial management rules apply here similarly as they do in the case of production management. Just like logistics management, financial management is a trigger of SM.

- Management of intangible assets (only present in the 2014 list of subdisciplines). This subdiscipline covers the issues of organizational culture, which seems to be an extremely well-researched topic in the field of management. However, it seems that more research into organizational culture is required in service environments. Culture is even more important to services than it is to production because, in the former case, employees interact with the customer more often. This view is up-to-date even for mass IT services, e.g. in the event of loss of Internet access by recipients, it is very important how the Internet provider addresses the problem. In the case of a defective item, the response is usually less complicated and is largely limited to its replacement. Therefore, SM can enrich the management of intangible assets by providing new perspectives.

Moreover, the operational and strategic level subdisciplines have a close relationship with service management. As shown in this analysis, SM makes extensive use of the achievements of other subdisciplines. It also offers its own outlook - a close customer relationship perspective - which gives meaning to all the other activities of the business organization. Without proper management of these relations, it would not be possible for other areas of management to function efficiently. It would not be possible to manage human resources, since without customers no human resources are needed; 
there is no need to manage information if there is no customer for whom information would be collected. Managing customer relations to create value is the subject of service management. Therefore, we may conclude that service management is becoming one of the leading subdisciplines, and certainly one of the leading perspectives for management. Research conducted in the proposed scope of SM translates into a better understanding of company goals and the appropriate positioning of other organizational processes.

The purpose of this article was to verify the scope of SM proposed by the team led by Cyfert. This range has been presented as follows:

- service design;

- shaping relationships in service management;

- service organization models;

- shaping the value of services.

This verification was largely positive, and the scope presented in this article completes and clarifies the scope established in 2014 and 2019. Moreover, our article adds an element of control through service quality management, thus completing the theoretical scope of service management. This scope elucidates the context and the issue of the subdiscipline's separateness. Furthermore, the article explains why the subdiscipline exists: value creation that is best delivered by effective service management. This scope operates by means of the service management system. Finally, our article should provide an answer to the question of whether we do what we planned to do. The latter is achieved through service quality management. Thus, we may conclude that the presented scope meets these needs.

Moreover, our analysis results are important for practice, as they summarize the research and observations made over a period of half a century. Over these five decades, the scope of what SM is has evolved until it reached the shape discussed in this article. The proposed scope allows organizations to relate to areas that will help them achieve service delivery goals in the context of their business. The presented scope/ structure of SM can help organizations undergo digital and service-oriented transformations. What is certainly required is further research on activities at the intersection of new technologies and services offered. As mentioned in this article, this is a very dynamic area that may shape not only the future scope of management but also the future nature of the economy. 


\section{References}

Alter, S. (2017). Answering Key Questions for Service Science. Proceedings of the $25^{\text {th }}$ European Conference on Information Systems (ECIS). Guimarães, Portugal, June 5-10, pp. 1825-1826.

Andersen, M. and Ankerstjerne, P. (2014). Service Management 3.0 - the next generation of service, ISS White Article.

Atkinson, L. et al. (1988). The Manager's Handbook. London: Sphere.

Bełz G., Cyfert S., Czakon W., Dyduch W., Latusek-Jurczak D., Niemczyk J., Sopińska A., Szpitter A., Urbaniak M., Wiktor J. (2019). Subdyscypliny w naukach o zarzqdzaniu i jakości 2.0. Komitet Nauk Organizacji i Zarządzania Polskiej Akademii Nauk. Obtained from: www.knoiz.pan.pl/ images/stories/pliki/pdf/Subdyscypliny_nauk_o_zarzdzaniu_i_jakoci.pdf (access: 3.05.2021).

Benkenstein, M., Bruhn, M. Büttgen, M., Hipp, Ch., Matzner, M. and Nerdinger, F. (2017). Topics for Service Management Research - a European Perspective. Journal of Service Management Research, 1. https://doi.org/10.15358/2511-8676-2017-1-4.

Bordoloi, S., Fitzsimmons, J. and Fitzsimmons, M. (2018). Service Management: Operations, Strategy, Information Technology. London: McGraw Hill.

Buera, F. and Kaboski, J. (2012). The Rise of the Service Economy. New York: National Bureau of Economic Research. https://doi.org/10.1257/aer.102.6.2540.

Cantone, L., Testa, P. and Marrone, T. (2019). Service-Dominant Logic: Inward and Outward Views. Cited in: P.P. Maglio et al. (eds.), Handbook of Service Science, Vol. II; Service Science: Research and Innovations in the Service Economy, Springer, 675-676. https://doi.org/10.1007/978-3-319-98512-1_30.

Chesbrough, H. and Spohrer, J. (2006). Manifesto for Service Science. Communications of the ACM, 49(7). https://doi.org/10.1145/1139922.1139945.

Cronholm, S., Karu, K., Göbel, H., Hearsum, P. and Hero, P. (2017). IT Service Management: The Alignment of ITIL® Practitioner Guidance with Service-Dominant Logic, The 28th Australasian Conference on Information Systems, Hobart Australia, December 4-6, 2017.

Cyfert, S., Dyduch, W., Latusek-Jurczak, D., Niemczyk, J. and Sopińska, A. (2014). Subdyscypliny w naukach o zarządzaniu - logika wyodrębnienia, identyfikacji modelu koncepcyjnego oraz zawartość tematyczna. Organizacja i Kierowanie, 1(161), 42-44.

Cyrek, M. (2005). Współczesne zmiany struktury sektora usługowego. In: D. Kopycińska (ed.), Funkcjonowanie gospodarki polskiej w warunkach integracji i globalizacji. Szczecin: Katedra Mikroekonomii, Uniwersytet Szczeciński.

Debije, M. (2015). Better luminescent solar panels in prospect. Nature, 519. http://dx.doi.org/10.1038/519298a.

Demirkan, H. and Spohrer, J. (2018). Service Transformations Enabled by Digital: Smart Machines. Journal of Service Management Research, 8.

Dziwulski, J. and Ogrzebacz, T. (2017). Media społecznościowe jako element strategii zarządzania relacjami z klientem w dobie globalizacji. In: W. Harasim (ed.), Wpływ zglobalizowanego świata na zarzqdzanie. Warszawa: Wyższa Szkoła Promocji, Mediów i Show Businessu.

Eikebrokk, T. and Iden, J. (2017). Strategising IT service management through ITIL implementation: model and empirical test. Total Quality Management \& Business Excellence, 28, 3-4.

Fitzsimmons, J. and Sullivan, R. (1982). Service Operations Management. New York: McGraw-Hill.

Fuchs, V. (1968). The Service Economy. New York: National Bureau of Economic Research. 
Grönroos, C. (1990). Service Management: A Management Focus for Service Competition. International Journal of Service Industry Management, 1(1), 6-14. https://doi.org/10.1108/09564239010139125.

Grönroos, C. (1994). From Scientific Management to Service Management: A Management Perspective for the Age of Service Competition. International Journal of Service Industry Management, 5(1), 5-20. https://doi.org/10.1108/09564239410051885.

Grönroos, C. (2000). Service Management and Marketing: A Customer Relationship Management Approach. Chichester: Wiley.

Gummesson, E. (1994). Service Management: An Evaluation and the Future. International Journal of Service Industry Management, 5(1). https://doi.org/10.1108/09564239410051920.

Heineke, J. and Davis, M. (2007). The Emergence of Service Operations Management as an Academic Discipline. Journal of Operations Management, 25(2), 369-372. https://doi.org/10.1016/j.jom.2006.11.003.

Heskett, J., Sasser, W.E. and Hart, C. (1990). Service Breakthroughs: Changing the Rules of the Game. Toronto: Macmillan.

Hill, T.P. (1977). On goods and services. Review of Income and Wealth, 23, 318. https://doi.org/10.1111/j.1475-4991.1977.tb00021.x.

Inman, R. (ed.) (1988). Managing the Service Economy: Prospects and Problems. Cambridge: Cambridge University Press.

ITIL Service Strategy (2011). London: TSO.

ITIL 4 Foundation (2019). London: TSO.

Johnston, L.D. (2012). History lessons: Understanding the Decline in Manufacturing. MinnPost, February 22. Obtained from: https://www.minnpost.com/macro-micro-minnesota/2012/02/ history-lessons-understanding-decline-manufacturing/.

Johnston, R. (1994). Operations: From Factory to Service Management. International Journal of Service Industry Management, 5(1), 51-52. https://doi.org/10.1108/09564239410051902.

Johnston, R. and Clark, G. (2008). Service Operations Management: Improving Service Delivery. FT Prentice Hall.

Kanovska, L. (2020). Are Smart Service Manufacturing Providers Different in Cooperation and Innovation Flexibility, in Innovation Performance and Business Performance from Non-Smart Service Manufacturing Providers? Engineering Management in Production and Services, 12(4), 105-116. https://doi.org/10.2478/emj-2020-0031.

Keller, A. (2017). Challenges and Directions in Service Management Automation. Journal of Network Systems Management, 25(1). https://doi.org/10.1007/s10922-017-9437-9.

Koontz, H. and O’Donnell, C. (1969). Zasady zarzqdzania. Warszawa: PWN.

Kostera, M. and Śliwa, M. (2010). Zarzqdzanie w XXI wieku. Warszawa: Wydawnictwa Akademickie i Profesjonalne.

Koźmiński, A.K. and Jemielniak, D. (2008). Zarzqdzanie od podstaw. Warszawa: Wydawnictwa Akademickie i Profesjonalne.

Larivière, B., Bowen, D., Andreassen, T., Kunz, W., Sirianni, N., Voss, D., Wünderlichand, C. and De Keyser, A. (2017). Service Encounter 2.0: An investigation into the roles of technology, employees and customers. Journal of Business Research, 2. https://doi.org/10.1016/j.jbusres.2017.03.008.

Levitt, T. (1972). Production-Line Approach to Service. Harvard Business Review. https://hbr.org/1972/09/production-line-approach-to-service.

Levitt, T. (1976). The Industrialization of Service. Harvard Business Review. https:/hbr.org/1976/09/ the-industrialization-of-service. 
Van Looy, B., Gemmel, P., and Van Dierdonck, R. (2003). Services Management: An Integrated Approach, FT Prentice Hall.

Machuca, J., Gonzalez-Zamora, M., Aguilar-Escobar, V. (2007). Service Operations Management Research. Journal of Operations Management, 25. https://doi.org/10.1016/j.jom.2006.04.005.

Maglio, P., Vargo, S., Caswell, N. and Spohrer, J. (2009). The Service System is the Basic Abstraction of Service Science. Information Systems and e-Business Management, 7. https://doi.org/10.1007/s10257-008-0105-1.

Marginson, S. (1998). Value Creation in the Production of Services: A Note on Marx. Cambridge Journal of Economics, 22(5). https://doi.org/10.1093/cje/22.5.573.

Metters, R. and Marucheck, A. (2007). Service Management-Academic Issues and Scholarly Reflections from Operations Management Researchers. Decision Sciences, 38(2), 201-205. https://doi.org/10.1111/j.1540-5915.2007.00156.x.

Matzner, M. and Büttgen, M. (2018). Digital Transformation of Service Management. Journal of Service Management Research, 2. https://doi.org/10.15358/2511-8676-2018-2-3.

Megginson, L., Mosley, D. and Pietri, P. (1989). Management: Concepts and Applications. New York: Harper\&Row.

Muhlemann, A., Oakland, J. and Lockyer, K. (1995). Zarzq̨dzanie - produkcja i usługi, Warszawa: PWN.

Nissen, C. (2019). Service Science, Service-dominant Logic and ITIL 4 White Article. Obtained from: https://www.axelos.com/case-studies-and-white-articles/service-science-service-dominant-logic-and-itil-4.

Ng, I., Maull, R. and Smith, L. (2009). Embedding the New Discipline of Service Science: A Service Science Research Agenda. Service Operations, Logistics and Informatics, SOLI '09. IEEE/INFORMS International Conference. https://doi.org/10.1109/SOLI.2009.5203906.

Nogalski, B. and Rokicki, A. (2020). Technological Progress and Management Studies. Scalability and Sustainability of Business Models in Circular, Sharing and Networked Economies. Cambridge Scholars Publishing.

Nogalski, B. and Karpacz, J. (2012). Orientacja na klienta a innowacyjność przedsiębiorstwa produkcyjnego. Prace Naukowe Uniwersytetu Ekonomicznego we Wrocławiu, 260, 328-339.

Normann, R. (1984). Service Management: Strategy and Leadership in Service Business. Wiley.

Pavlov, O. and Hoy, F. (2018). Entrepreneurship Education as a Service. In: G.T. Bosio, T. Minola, F. Origo and S. Tomelleri (eds.), Rethinking the Entrepreneurial Human Capital: The Role of Innovation and Collaboration. Cham, Switzerland: Springer.

Pinhanez, C. and Kontogiorgis, P. (2008). A Proposal for a Service Science Discipline Classification System. IBM Corporation.

http://citeseerx.ist.psu.edu/viewdoc/download?doi=10.1.1.626.80\&rep=rep1\&type=pdf

Rogoziński, K. (2018). Service dominant logic - intelektualny przekręt? Ekonomiczne Problemy Usług, 130(1), 141-152. https://doi.org/10.18276/epu.2018.130-14.

Sasser, W. (1976). Match Supply and Demand in Service Industries. Harvard Business Review. https://hbr.org/1976/11/match-supply-and-demand-in-service-industries.

Sasser, W., Olsen, R. and Wyckoff, D. (1978). Management of Service Operations: Text, Cases and Readings. Boston: Allyn and Bacon.

Shrestha, A., Cater-Steel, A. and Toleman, M. (2016). Innovative Decision Support for IT Service Management. Journal of Decision Systems, 25, https://doi.org/10.1080/12460125.2016.1187424.

Spohrer, J. and Kwan, S. (2009). Service Science, Management, Engineering, and Design (SSMED): An Emerging Discipline - Outline and References. International Journal of Information Systems in the Service Sector, 1(3), 9-18. https://doi.org/10.4018/jisss.2009070101. 
Stoshikj, M., Kryvinska, N. and Strauss, C. (2016). Service Systems and Service Innovation: Two Pillars of Service Science. Procedia Computer Science, 83. https://doi.org/10.1016/j.procs.2016.04.118.

Vargo, S. and Lusch, R. (2006). Service-dominant Logic: What it is, what it is not, what it might be. In: M.E. Sharpe (ed.), The Service Dominant Logic of Marketing: Dialog, Debate, and Directions. https://doi.org/10.1007/s11747-015-0456-3.

Vargo, S. and Lusch, R. (2016). institutions and Axioms: An Extension and Update of Service-dominant Logic Journal of the Academy of Marketing Science, 44(5).

Walker, R. (2004). Is There a Service Economy? The Changing Capitalist Division of Labor. In: T. Barnes, J. Peck, E. Sheppard, A. Tickell (eds.), Reading Economic Geography. Wiley-Blackwell. https://doi.org/10.1002/9780470755716.ch6.

Wróbel, A. (2009). Międzynarodowa wymiana usług. Warszawa: Wydawnictwo Naukowe Scholar.

Zaborek, P., and Mazur, J. (2019). Enabling value co-creation with consumers as a driver of business performance: A dual perspective of Polish manufacturing and service SMEs. Journal of Business Research, 104, 541-551. https://doi.org/10.1016/j.jbusres.2018.12.067.

Zhao, G., Perros, H. and Xin, Z. (2009). How Service Science Management and Engineering (SSME) can evolve to an academic discipline. International Journal of Web Engineering and Technology. https://doi.org/10.1504/IJWET.2009.032257. 